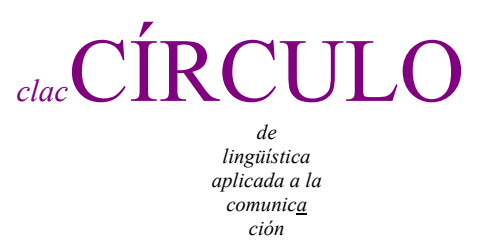

$65 / 2016$

\title{
THE GRAMMATICALIZATION AND PRAGMATICALIZATION OF THE \\ ROMANIAN INDEFINITE PRO-FORMS: A CORPUS-BASED APPROACH
}

Alice Preda Bodoc and Monica Ardeleanu Gomoescu

Transilvania University of Brasov

alice_bodoc at yahoo.com, gomoescu monica at gmail com

\begin{abstract}
The present paper aims to explore, and address some issues concerning the Romance diachronic morphosyntax in the light of theoretical and methodological considerations on the grammaticalization and pragmaticalization phenomena, and the question of linguistic change. Building on the previous work concerning grammaticalization, we intend to reveal a pragma-linguistic scenario that accounts for the actual situation of the Romanian indefinite compounds. We consider this subject to be very particular, meaning that the historical development of these pro-forms is not a canonical case of grammaticalization or pragmaticalization.
\end{abstract}

Key words: grammaticalization, pragmaticalization, indefinite pro-forms, Romanian

Preda Bodoc, Alice and Monica Ardeleanu Gomoescu. 2016.

The grammaticalization and pragmaticalization of the Romanian indefinite pro-forms: a corpus based approach.

Círculo de Lingüística Aplicada a la Comunicación 65, 223-256.

http://www.ucm.es/info/circulo/no65/preda.pdf.

http://revistas.ucm.es/index.php/CLAC

http://dx.doi.org/10.5209/rev_CLAC.2016.v65.51987

(C) 2016 Alice Preda Bodoc and Monica Ardeleanu Gomoescu

Círculo de Lingüística Aplicada a la Comunicación (clac)

Universidad Complutense de Madrid. ISSN 1576-4737. http://www.ucm.es/info/circulo 
Contents

1. Introduction 225

2. Definition, form and etymology of the indefinite pro-forms 225

3. Data and methodology 226

3.1. General considerations on the data 226

3.1. Methodology 227

3.1.1. Grammaticalization 227

3.1.2. Pragmaticalization 228

4. Romanian indefinite pro-forms: results 229

4.1. The Old Romanian language $\left(16^{\text {th }}-18^{\text {th }}\right.$ c. $) 229$

4.2. Modern Romanian language $\left(19^{\text {th }}-20^{\text {th }}\right.$ c. $) 239$

4.2.1. Indefinite pro-nouns 239

4.2.2. Pro-adverbs and connectors 241

4.3. The Present-Day Romanian language ( $21^{\text {st }}$ c.) 242

4.3.1. Indefinite pro-nouns, also used in some contexts as pro-adjectives and connectors 242

4.4. The grammaticalization and pragmaticalization of the Romanian indefinite proforms 245

4.4.1. General considerations 245

4.4.2. Case study - the grammaticalization scenario of the indefinite pro-noun oarece/orice 246

4.4.3. Case study - the grammaticalization and pragmaticalization of the indefinite pro-adverb oricum 249

5. Final considerations 252

Sources and acronyms 253

References 254

clac $65 / 2016,223-256$ 


\section{Introduction ${ }^{1}$}

Language change, with a focus on grammaticalization and pragmaticalization, is considered to be an essential and universal feature of human language, and, by investigating the laws of language change, we learn a great deal about language in general. As concerns grammaticalization, it has been underlined that the same set of processes and mechanisms are responsible for all aspects of grammar. Thus, all grammatical morphemes have developed out of lexical morphemes, principally nouns and verbs, and all grammatical structures have developed out of more loosely organized constituents (Bybee 2003), as in the case of indefinite pro-forms that developed out of verbs. Above all the controversies relating to the origin of these pro-forms, there are still many questions unanswered regarding the evolution steps and the relation existing between the forms that have coexisted for long periods in language use.

The next four sections of the article define the subject of the present study and describe the forms of these Romanian linguistic items (Section 2), present the methodological framework and some considerations on the data (Section 3), investigate the indefinite pro-forms in three stages of the Romanian language evolution and underline the grammaticalization/pragmaticalization phenomenon (Section 4), and summarize the final considerations (Section 5).

2. Definition, form and etymology of the indefinite pro-forms

Indefinite pronouns are pronouns whose main function is to express indefinite reference. (Haspelmath 1997: 10-11) In our study we will use the cover term pro-forms proposed by Haspelmath, comprising pro-nouns, pro-adverbs and pro-adjectives. (Vater 1975 apud Haspelmath 1997: 10)

Although the paradigm of these pro-forms in the Romanian language is large, we shall focus only on the indefinite pro-nouns and pro-adverbs constructed with

\footnotetext{
${ }^{1}$ This paper is supported by the Sectoral Operational Programme Human Resources Development (SOP HRD), ID134378 financed from the European Social Fund and by the Romanian Government.
} 
oare/vare/ori/veri, as these forms have been involved in processes of grammaticalization and pragmaticalization.

The pro-forms analysed here are structured as compounds:

vare/oare/ori/veri ('any' - proclitic element) + care, cine, ce, cât, ('which', 'who', 'what', 'how much' - relative pronouns)

vare/oare/ori/veri ('any' - proclitic element) + unde, când, cum, cât ('where', 'when', 'how', 'how much' - relative adverbs)

From a large number of etymological debates on the roots of the indefinite particles we embrace the perspective that proposes the lat. volet (according to the alb. valle) as the historical origin of oare, while the term ori is the result of the transformation of vare/oare through some syntactic and phonetic criteria ${ }^{2}$ (Dimitrescu 1974). As it shall be demonstrated in our research, this hypothesis is confirmed by a large number of contexts in which oare appears with the disjunctive meaning ori.

Analysed from a diachronic perspective, indefinite pronouns are considered to arise from a limited number of sources, the most common being phrases with original meanings such as whatever it may be, it does not matter which, or it is the same which, which come to acquire the 'free choice' function and then spread first to the functions adjacent to it and then to more distant ones (O Dahl 2005).

\section{Data and methodology}

3.1. General considerations on the data

The corpus analysed in this paper includes 22 texts (religious and laic) in original and translation, comprising over 500,000 words and covering the period of $16^{\text {th }}-18^{\text {th }} \mathrm{c}$. For

\footnotetext{
${ }^{2}$ Dimitrescu (1974: 175-176) - "Ori nu provine din voles (cf. Rosetti), ci se explică prin criterii fonetice tot din vare/oare. (cf. Candrea, Densusianu - Dicționarul etimologic al limbii române, 1907-1914).”

["Ori does not come from voles (according to Rosetti), but it can be explained based on fonetic criteria as originating from vare/oare (according to Candrea, Densusianu - Dicționarul etimologic al limbii române, 1907-1914).”]
} 
the comparison with the present-day Romanian, we used Romanian grammar and history of the language studies, such as GALR (2008), The Grammar of Romanian (RG 2013), Gramatica de bază a limbii române ( GBLR 2010) and Studii de istorie a limbii române (SILR 2012). The data extracted has been organized into three periods, reflecting the conventional time division proposed by linguists: Old Romanian $\left(16^{\text {th }}\right.$ $18^{\text {th }}$ c.), Modern Romanian $\left(19^{\text {th }}-\right.$ until the middle of the $20^{\text {th }} \mathrm{c}$.), Contemporary Romanian and Present-day Romanian (second half of the $20^{\text {th }}$ c. $-21^{\text {st }}$ c.).

\subsection{Methodology}

\subsubsection{Grammaticalization}

Taking the definitions, the characterizations, and the identified parameters (Lehmann 1995), principles (Hopper 1991) and characteristics (Brinton and Traugott 2005), as a starting point, Beijering (2012) proposes a new approach to grammaticalization in which formal reanalysis ${ }^{3}$ (language change) and semantic reinterpretation are equally important. She distinguishes between two types of grammaticalization, viz. primary grammaticalization (Gzn1) (from lexical to grammatical status), and secondary grammaticalization (Gzn2) (from grammatical to (more) grammatical status) and proposes the following definition of grammaticalization:

Grammaticalization is a composite type of language change whereby lexical or already grammaticalized items, in certain linguistic contexts, undergo both semantic reinterpretation and formal reanalysis. It is accompanied by a subset of correlated primitive changes and side effects. Grammaticalization leads to a grammatical item, i.e. a linguistic item belonging to a minor category, with

\footnotetext{
${ }^{3}$ In this paper we take into consideration the following definition of reanalysis given by Beijering (2012: 37): Reanalysis is a covert operation that results in a new structural representation for a given linguistic string that is not immediately noticeable at its surface manifestation. There are different types of reanalysis that apply to different linguistic levels (hierarchical structure, constituent structure and category label), but there is no generally accepted terminology to refer to its subtypes.
} 
relational meaning, secondary status, the prime function of which is to regulate grammatical structure and grammatical relations. (Beijering 2012: 47)

From this perspective, Gzn1 implies categorical reanalyses (formal reanalysis from major to minor category) and reinterpretation (semantic reinterpretation from referential to relational meaning), and it is accompanied by a set of primate changes, such as: loss of morphosyntactic properties (attrition) and loss of semantic substance (bleaching), and followed by side effects: increase in paradigmaticity, structural scope reduction, layering (synchronic variation of a given form), divergence (split), specialization, persistence, context expansion, increased type and token frequency and typological generality (cross-linguistic patterns). On the other hand, Gzn2 implies formal reanalysis from minor to minor category (categorial reanalyses), and semantic reinterpretation of relational meanings, being accompanied mandatorily only by loss of semantic substance (bleaching) and followed by side effects as: increase in paradigmaticity, decrease of paradigmatic variability, structural scope reduction, layering (synchronic variation of a given form), divergence (split), specialization, persistence, productivity increased type and token frequency. (Beijering 2012)

\subsubsection{Pragmaticalization}

Considering the proposed definitions (Erman and Kotsinas 1993, Diewald 2011) and the identified characteristics (Aijmer 1997) as a departure point, Beijering (2012) proposes a new definition of pragmaticalization (Pgzn):

Pragmaticalization can be thought of as the study of the origin and rise of discourse markers, as well as the gradual diachronic change leading to discourse markers. i.e. a linguistic item with conversational meaning, extrapropositional status, the prime function of which is to organize discourse structure. (2012: 56)

Thus, Pgzn implies hierarchical reanalyses, meaning formal reanalysis from propositional to extra-propositional status and semantic reinterpretation from 
referential/relational meaning to conversational meaning (=(inter)subjectification ${ }^{4}$ ), is accompanied by loss of semantic substance (bleaching) and gain of speaker's perspective (subjectification) and is followed by a set of side effects: layering (synchronic variation of a given form), divergence (split), specialization, persistence, productivity (context expansion) and increased type and token frequency (Beijering 2012).

4. Romanian indefinite pro-forms: results

\subsection{The Old Romanian language $\left(16^{\text {th }}-18^{\text {th }} \mathrm{c}.\right)$}

Starting with the first attested Romanian text - Psaltirea Hurmuzaki (1500) - we noticed the co-occurrence of the indefinite pro-forms, both composed with oare (vare) and ori. This fact demonstrates that all these compounds formed in an earlier stage of the Romanian language, meaning the Common Daco-Romanian $\left(13^{\text {th }}-14^{\text {th }} \mathrm{c}\right.$.). These were used in spoken language or in texts that have not been conserved until present time, and this explains the free variation of the forms at the beginning of the Old Romanian language.

Basically, the forms identified in the corpus extracted for this period can be organized and analysed as follows:

\section{A. Indefinite pro-nouns, also used in some contexts as pro-adjectives and connectors}

a. Vare-series: vare (în) ce, vare cealea, vare (întru) care, vare (pre) cine, vare (pre) câți, varece/voarece, varecare, varecine, varecît

b. Oare-series: oare (prin/în) ce, oare cine, oare care, oarecine, oarecare, oareşcare, oareşicare, oarece, oareceş, oareşce, oarecât, oaricîte, oarecîteva

\footnotetext{
4 "Subjectification and intersubjectification are metonymic types of semantic change that lead to increased speaker-perspective, attitude or judgment (subjectification) and attention to speaker-addressee interaction (intersubjectification)." (Beijering 2012)
} 
c. Ori-series: ori (de) cine, ori (asupra) căruia, ori (în/de/pre) care, ori (de/la/în/ cu/din/pre/supt) ce, ori (la) câte, oricine, oricare, orice, oricât

d. Veri-series: veri cine, veri (în/pentru/cu/de pe/din) ce, veri (întru/din) care, veri cite, vericine, verice, vericarii, vericarele, vericui

Taking the case of oarecine/varecine/oricine ('anyone'), we will show that the pronouns (1) can also be used as pro-adjectives (2) (even in the same text), situation that is very peculiar considering the exclusive pro-nominal use of these forms in the Presentday Romanian language.

$\begin{array}{clllll}\text { când } & \text { caută } & \text { oarecine să } & \text { se } & \text { îmbogăţească } \\ \text { when } & \text { tries } & \text { someone.NOM SĂ } & & \text { CL.REFL.ACC } & \text { grow.rich.SUBJ.3SG }\end{array}$

(FD.1592-1604: 499 $)$

'when someone is trying to grow rich...'

(2)

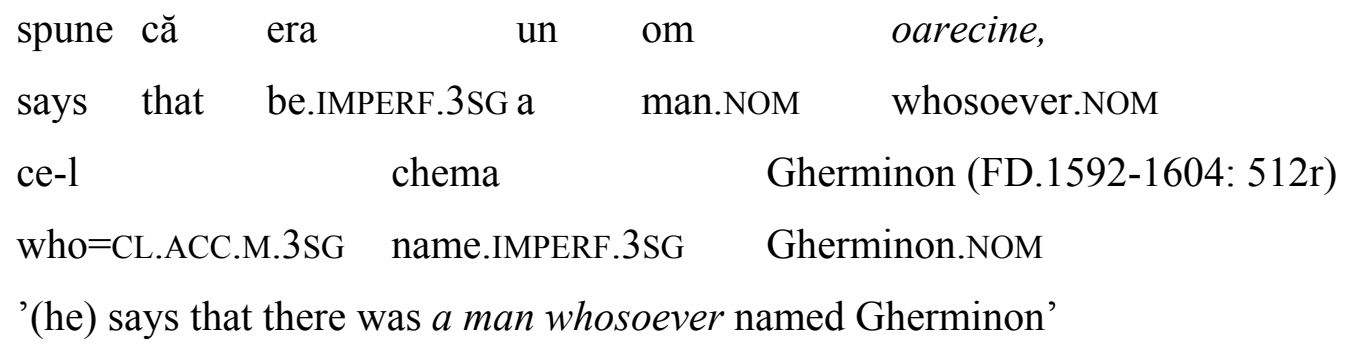

In (3) we notice the free variation of varece and oarece ('anything') in the same phrase from a religious text:

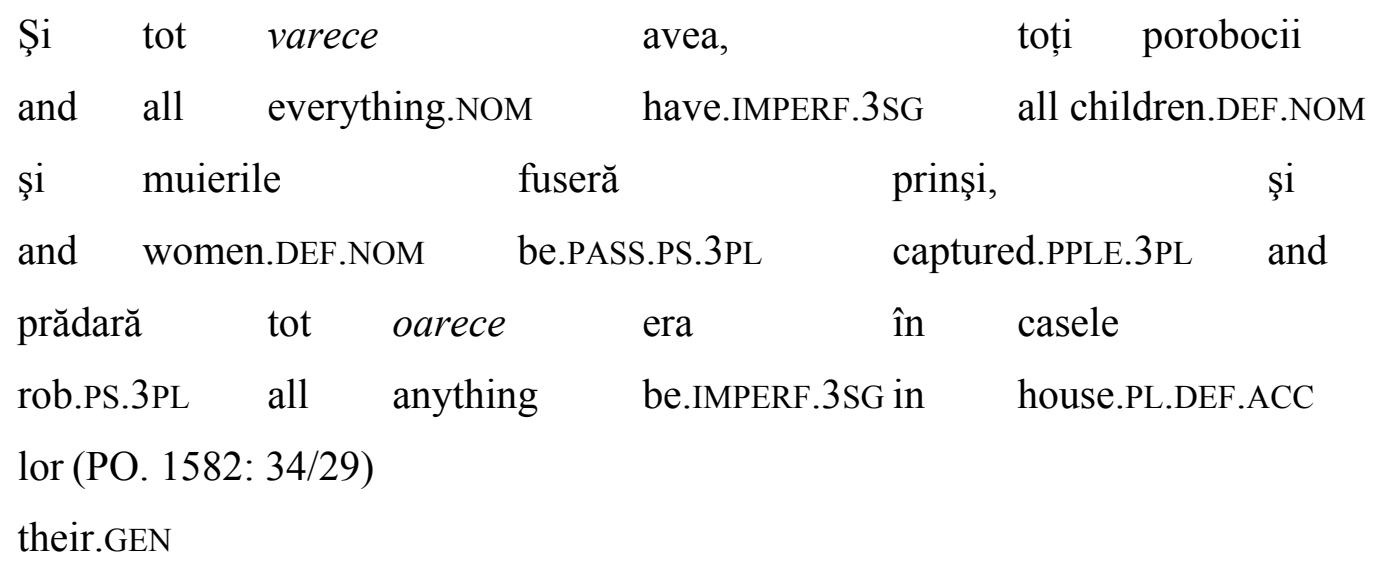

'And they captured everything they had, all their children and women, and robbed anything they had in their houses.'

There are cases in which the pro-noun functions as head of the NP (4) and is followed by a preposition (dentre, dintru, den), or as a noun (5), carrying an indefinite article: 
(4)

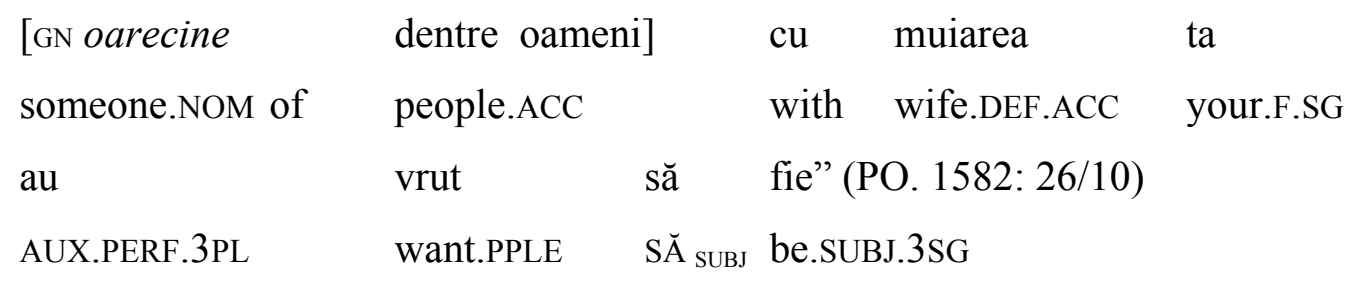
'someone (of the people) wanted to be with your wife'

(5)

$\begin{array}{lllll}\text { Întru } & \text { aceale } & \text { zile } & \text { să } & \text { născu } \\ \text { In } & \text { those.F.ACC } & \text { days.ACC } & \text { CL.REFL } & \text { be.born.PS.3SGa } \\ \text { un } & \text { oarecarile } & & & \end{array}$

someone.NOM

$\begin{array}{lll}\text { Numele } & \text { lui }- & \text { Noe (MPI. fin.17th. c.: } 8^{v} \text { ) } \\ \text { name.DEF.NOM } & \text { his.GEN } & \text { Noah.NOM }\end{array}$

'Those days, someone was born, his name was Noah.'

The prevalent syntactic function of the pro-noun is that of sentence connector, taking sometimes a relative value (6):

(6)

\begin{tabular}{|c|c|c|c|c|c|c|c|}
\hline $\begin{array}{l}\text { Nime } \\
\text { nobody }\end{array}$ & & $\begin{array}{l}\text { nu } \\
\text { not }\end{array}$ & $\begin{array}{l}\text { ştie } \\
\text { knows }\end{array}$ & $\begin{array}{l}\text { cine } \\
\text { who.NO }\end{array}$ & $\begin{array}{l}\text { iaste } \\
\text { is }\end{array}$ & $\begin{array}{l}\text { Fiiul, } \\
\text { Son.DEF.NOM }\end{array}$ & $\begin{array}{l}\text { fără } \\
\text { without }\end{array}$ \\
\hline numai ' & Tatăl & & & şi & varecui & va & vrea \\
\hline only & Father. & r.DEF.NOM & & and & anyone.DAT & AUX.FUT.3SG & want.INF \\
\hline Fiiul & & să-i & & & arate. (NT.16 & 48: $\left.234 / 82^{r}\right)$ & \\
\hline Son.DEF & F.NOM & S $\check{S}_{\text {SUBJ. }}=C$ & $=$ CL.DAT & & reveal.SUBJ.3 & & \\
\hline
\end{tabular}

'No one knows who the Son is, except the Father, and anyone whom the Son wants to reveal himself'

As far as the pro-adjectival use is concerned, the texts revealed two situations: one in which the pro-form is located in front or after the modified noun (7), and another one in which the pro-adjective takes a fixed position - in front of the noun with a preposition (de, la, in, cu, din, pre, supt, asupra) interposed between the two elements of the compound pro-form (8):
(7) să-i
arate
oareşcare semnu.ACC al
$S \check{S A U B}_{\mathrm{SU}}=\mathrm{CL}$.DAT
show.SUBJ.3SG some.ACC sign.ACC
AL.M.SG
dragostii [...] (Fil. ante 1837: 16)
love.DEF.GEN
'to show him some sign of love' 
(8)

\begin{tabular}{lllll} 
Şi vare & $\hat{\imath} n \quad c e$ & oraş & veți întra & \multicolumn{1}{c}{ şi } \\
any in & what.ACC & town.ACC & AUX.FUT.3PL enter.INF and \\
vă & & vor & priimi, & mîncaţi. (NT.1648: 233/81 \\
CL.ACC.2PL & AUX.FUT.3PL & welcome.INF & eat.IMP.2PL
\end{tabular}

'And in any town you will get and you will be welcomed, do eat!'

Certain writers prefer the second case, an example being Dosoftei, who, in Psaltirea in versuri, makes use of 23 interposed constructions out of 33 contexts with pro-forms.

In some of the contexts in which the pro-forms function as connectors of headed relative clauses, the head is represented by the quantifier tot (9):

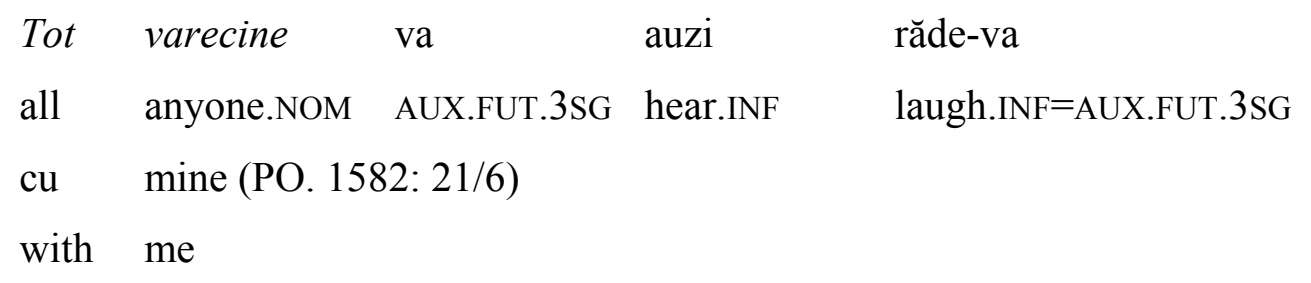

'all anyone who shall hear would laugh of?/with? me'

In addition, there are some examples in which the pro-form, having a quantificational value, is doubled by another (pseudo)quantifier: alt ('other') (10), puțin ('little') (11)
E alţii
amu şi alte
oareceş
and others.NOM now and other.F.PL something
striga. (CPr. 1563: 92)
Scream.IMPERF.3PL
'Now, others were screaming some (other) things.'
(11) Păsați iară şi cumpărați oarece puțină hrană (PO. 1582: 43/2) go.IMP.2PL again and buy.IMP.2PL some little food.ACC
'Go again and buy some food.'

Considering the co-occurrence of the pro-forms constructed with oare + care/cine, we noticed that, apart from their pro-nominal or pro-adjectival use, the forms reveal gender (oarecarea for the feminine (12)/ oarecarele for the masculine (13)), number (oarecare for the singular (14)/ oarecarii for the plural (15)) and case (oarecine (16)/ oarecui (17)) distinctions undertaken only by their relative compound.
(12) i-au
arătat
lui o
parte
CL.DAT.3SG=AUX.PERF.3PL
show.PPLE
he.DAT a
part 


$\begin{array}{lll}\text { oarecarea } & \text { de } & \text { norod (Biblia Blaj: 22/41) } \\ \text { some.DEF.F.SG } & \text { of } & \text { people }\end{array}$

'...they showed him some part of the people.'

(13) De corabiia aceasta un înțelept oarecarele la about boat.DEF.ACC this.F.ACC a wise.man.NOMsome.DEF.M.SG to arătare $\quad$ vesteşte (MPI. $\sim$ mijlocul sec. XVII: 10r)

vision.ACC tell.PRES.3SG

'When foreseeing the boat, some wise man tells them about it'

$\begin{array}{llll}\text { oarecare } & \text { inger } & \text { s-au } & \text { atins } \\ \text { some } & \text { angel.NOM } & \text { CL.REFL.ACC.3SG=AUX.PERF.3SG } & \text { touch.PPLE } \\ \text { de } & \text { dânsul (Biblia Blaj: } 19 / 5) & \\ \text { of } & \text { him.ACC } & \end{array}$

'some angel touched him'

(15) Deci de vor grăi oarecarii că fu so if AUX.FUT.3PL say.INF anyone.M.PL that was lepădat... (MPI. middle of the $17^{\text {th }}$ c.: $2^{\text {r }}$ )

repulsed.PPLE

'So, if anyone will say that he was repulsed...'

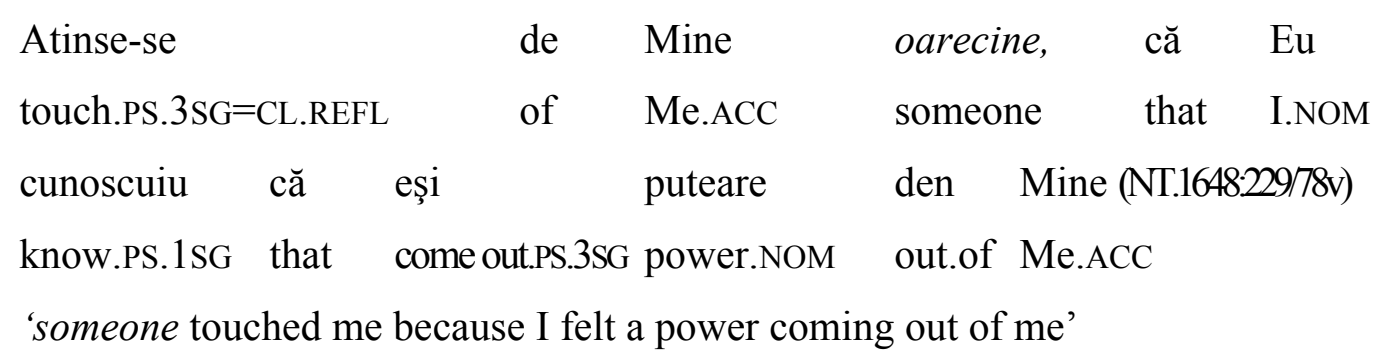

$\begin{array}{lllll}\begin{array}{l}\text { întră } \\ \text { enter.PS.3SG in }\end{array} & \text { casa } & \text { oarecui } & \text { de-1 } \\ \text { chiema } & & \text { Iust (NT.1648: 344/159r). } \\ \text { call.IMPERF.3SG } & \text { Iust.NOM }\end{array}$

'(He) entered someone's house whose name was Iust'

An intriguing case is represented by the use of the form specialized for the masculine with a feminine noun (18):

$\begin{array}{rlrll}\text { (18) Şi } & \text { era acolo } & \text { o } & \text { muiare } & \text { oarecarele, } \\ \text { And } & \text { be.IMPERF.3SG there } & \text { a } & \text { woman.NOM } & \text { some.DEF.M.SG }\end{array}$ 


$$
\begin{aligned}
& \text { numele } \quad \text { ei }-\quad \text { Armatema (MPI. } \sim \text { middle of the } 17^{\text {th }} \text { c.: } 323 \mathrm{v} \text { ) } \\
& \text { name.DEF.NOM her.GEN Armatema.NOM }
\end{aligned}
$$

The veri- series was first identified in our data from the $17^{\text {th }} \mathrm{c}$., in the Bible from 1688 (Bucharest) (19).

$$
\begin{aligned}
& \text { Invăţătoriule, vom ca verice } \quad \begin{array}{l}
\text { vom } \\
\text { Master.VOC }
\end{array} \text { want.PRES.1PL that everything AUX.FUT.1PL ask.INF } \\
& \text { să } \quad \text { faci } \\
& \text { Soao. (BB.1688: 782) } \\
& \text { 'Master, we want You to accomplish everything we will ask you for' }
\end{aligned}
$$

In the $18^{\text {th }} \mathrm{c}$, in some religious texts, these pro-forms appear in free variation with the oare- and ori- series. So, the veri- compounds carry all possible values: with prepositions interposed (20), or having pronominal (21)/adjectival (22) value.

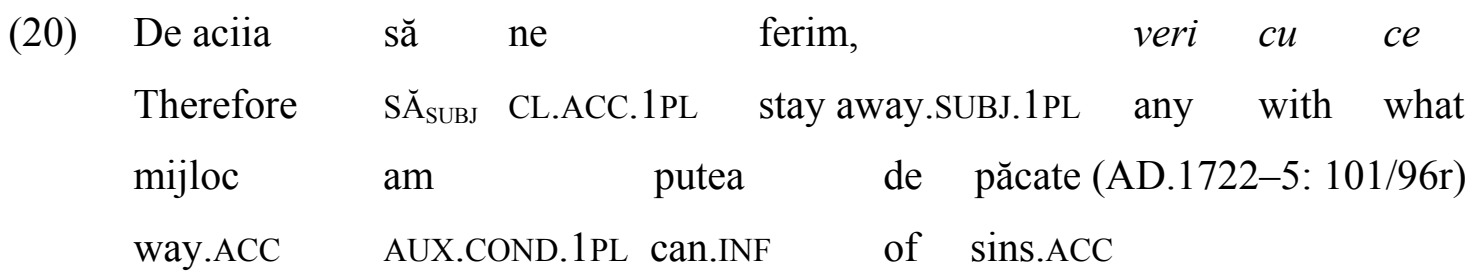

'That is why we should stay away of sins, in every way we can'

(21) Că vericari din voi nu veți purta de grijă să

that anyone of you not AUX.FUT.2PL care.INF SĂ $\check{S U B J}_{\text {. }}$

faceți aşa (AIS.1705: 380/39r)

do.SUBJ.2PL like.this

'That any of you who will not be careful to do like this...'

(22) A zecea poruncă zice să nu pohtim

tenth.FEM Commandment.NOM says SĂ $\check{S U B J}_{\text {Su }}$ not crave.SUBJ.1PL

verice lucru strein (AD.1722-5: 33/30v)

any thing.ACC foreign

'The $10^{\text {th }}$ Commandment says that we should not crave for anything that is not ours.'

Our research on the old period of Romanian language revealed the early use of the indefinite pro-form as a general extender (23), forms that generalize during the next 
periods of language formation. This singular case can represent the first sign of the pragmaticalization process of such pragmatic markers ${ }^{5}$ as the use of the marker implies that there is more to be said, but the author resorts to shared knowledge.

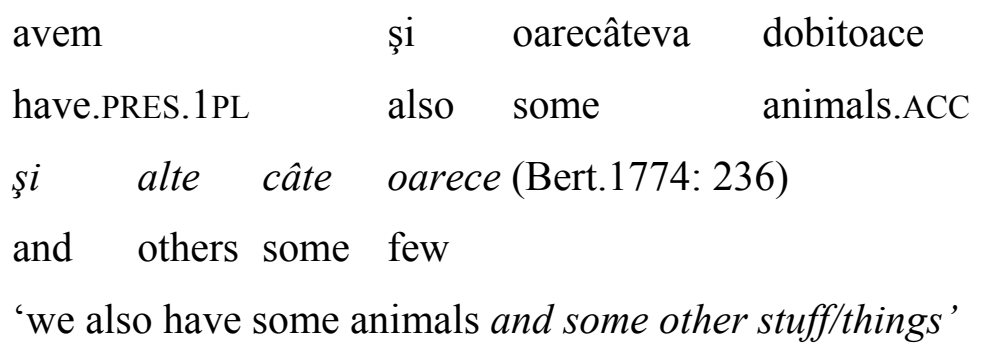

\section{B. Pro-adverbs and connectors}

a. Vare-series: varecum, vareunde, vareîncotro, varecât, vare cu cât,

b. Oare-series: oarecând(u), oarecum, oareunde, oare unde, oare-încătruo

c. Ori-series: oricum, oriunde, oricând

d. Veri-series: veriunde, vericât

As our data confirms, interrogative pronouns represent one of the derivational bases of the indefinite pronouns (Haspelmath 1997) (24), the same being the case of the indefinite pro-adverbs (25):
Oare cine-i
mai mare întru Împărăţiia
ceriurelor?

INT who.NOM=is more big in kingdom.DEF.ACC

ceriurelor?

skies.DEF.GEN (NT.1648: 150/22 $2^{\mathrm{v}}$ )

'Who is there bigger in God's kingdom?'

$\begin{array}{llllll}\text { Oare cum } & \text { vă } & \text { pare } & \text { voao } & \text { de } & \text { a } \\ \text { INT how } & \text { CL.ACC.2PL feel.PRES } & \text { you.DAT } & \text { about } & \text { AL.F.SG.GEN } \\ \text { lui } & & \text { tăceare? (Sind.1703: 81r) } & & & \\ \text { his.GEN } & \text { silence.ACC } & & & \end{array}$

'How do you feel about his silence?'

\footnotetext{
${ }^{5}$ Pragmatic markers are 'surface phenomena'. On a deeper level they are reflexive i.e. they mirror the speaker's mental processes as envisaged in 'the fabric of talk-in-interaction' commenting on what goes on in the speaker's mind (Redeker 2006) (Aijmer 2013: 4).
} 
The indefinite value of these pro-adverbs overlaps their original meaning expressing time $($ vareloarelori $+c \hat{n} d(u))(26)$, place (vareloarelori + unde, vareîncotro, oareîncătruo) (27), manner (vare/oare/ori + cum) (28) or quantity (vare + cît) (29).

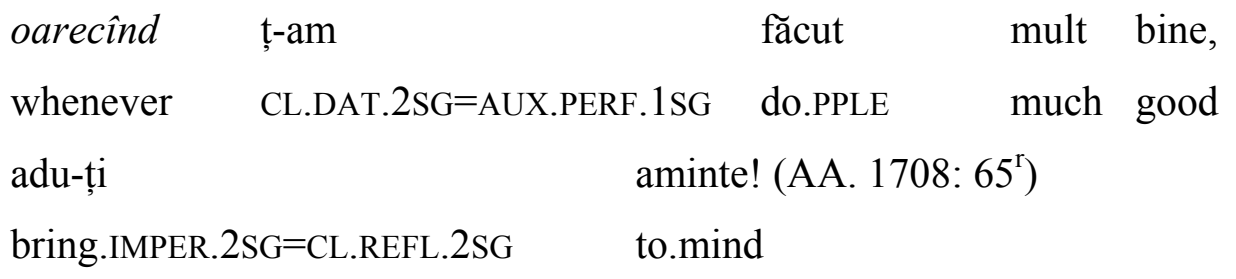

'remember the time when I did you so much good'

$\mathrm{Eu}$, oriunde şi la ce bătaie am fost,

I.NOM anywhere and to what fight.ACC AUX.PERF.1SG be.PPLE

niciodată nu m-au biruit (Fil. ante 1837: 10)

never not CL.ACC.1SG=AUX.PERF.3PL defeat.PPLE

'Anywhere and in any fight I was involved, I have never been defeated'

(28)

E cea giupâneasă socoti să-i facă

And that.F woman.NOM think.PS.3SG SĂ $\check{S U B J}=$ CL.DAT.3SG do.SUBJ.3SG

moarte oarecum lu Amon (FD.1592-1604: 562v)

death.ACC somehow LUI.DAT Amon

'And that woman thought to kill Amon in any way'

(29)

$\begin{array}{lllll}\text { Pasă, } & \text { vare cît } & \text { ai } & \text { vinde, } & \text { şi } \\ \text { try.IMPER.2SG } & \text { as.much.as } & \text { AUX.COND.2SG } & \text { sell.INF } & \text { and } \\ \text { dă } & \text { mişeilor }\left(\mathrm{CC}^{1} \text {.1567: } 114^{\mathrm{r}}\right) & & \\ \text { give.IMPER.2SG } \quad \text { poors.DEF.DAT } & \end{array}$

'As much as you'd sell, try to give to the poor, too'

Due to the fact that these forms were not yet tied, they appeared in free variation and there are contexts in which the pro-adverb oarecum (30) is used as periphrastic marker ${ }^{6}$ :

$\begin{array}{llllll}\text { (30) } & \text { Şi } & \text { aceasta } & \text { nebuniia } & \text { vine în } & \text { patru lucrure } \\ & \text { and } & \text { this.F.SG } & \text { craziness.DEF.NOM } & \text { comes in } & \text { four things.ACC }\end{array}$

\footnotetext{
${ }^{6}$ Our translation of the opération de reformulation. (Rossari 1994)
} 


$\begin{array}{lllllll}\text { oarecum: Întâiu, easte că } & \text { nu caută } & \text { nice } & \text { u(n) } \\ \text { as.follows first is that not considers } & \text { not } & \text { one } \\ \text { lucru (FD.1592-1604: } 529 \mathrm{v}) & & & & & \\ \text { thing.ACC } & & & & & \end{array}$

'And this craziness has four causes, as follows: the first one is that he does not consider anything'

The same reason seems to explain the contexts (31) in which this pro-adverb maintains its modal meaning, being in relation with a correlative $(a s ̧ a)$ :

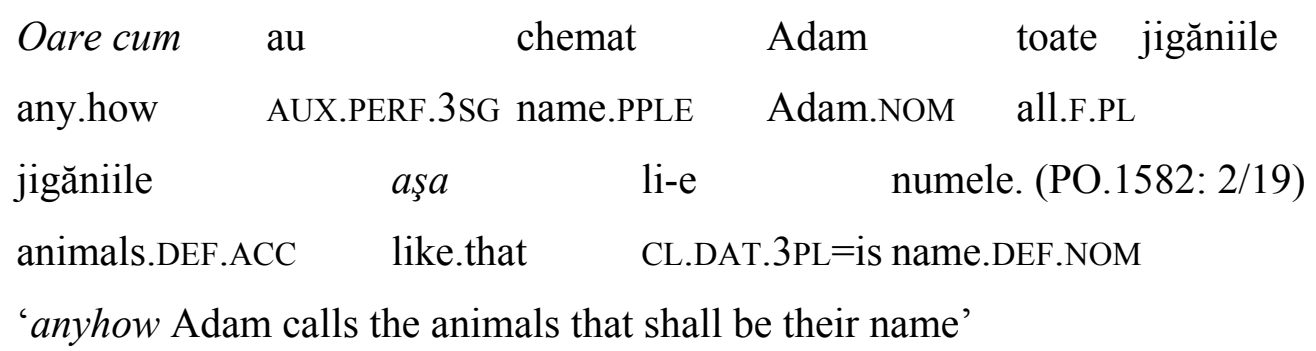

Our data revealed singular cases in which the indefinite pro-adverb is used as a proadjective, as in (32):
(32) easte o fire oarecum şi trage omul supt is a nature somehow and drags man.DEF.ACC under fire (FD.1592-1604:469r)
nature.ACC
'(that) is some kind of being that drags the man under its power'

There are also situations in which the indefinite pro-adverb oarecând (with a temporal meaning) is doubled by the relative time adverb când (33):

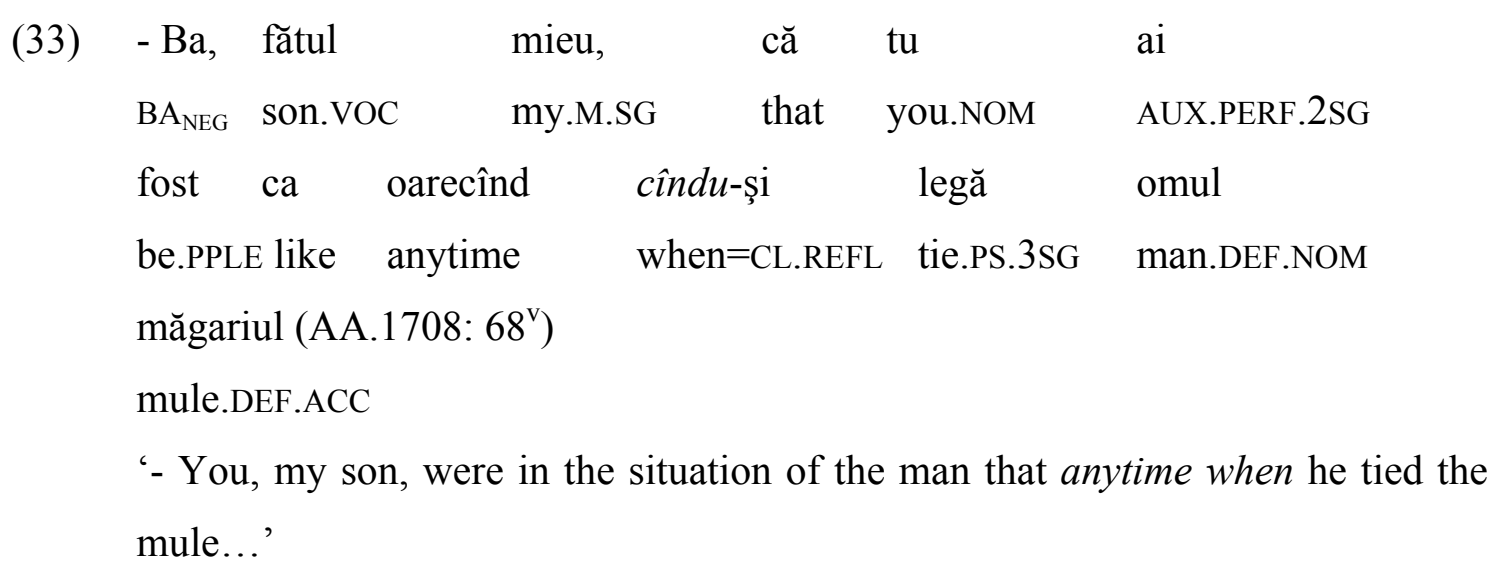


As compared to the large number (56 occurrences) of pro-nouns and pro-adjectives above mentioned, we discovered only one case of preposition interposed in the indefinite pro-adverbial construction (34):

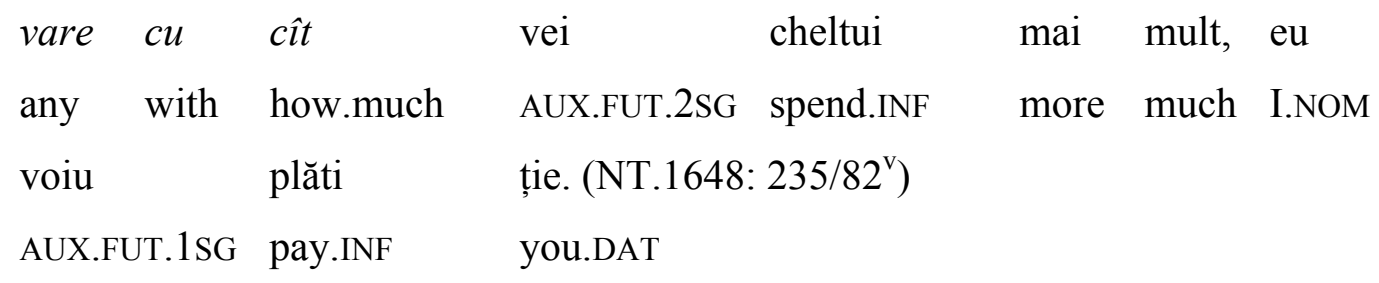

'As much as you will pay, I will pay it back to you.'

Among these pro-forms, there is the indefinite vareîncotro/oare-încătruo, specific only to the Old Romanian language, while its indefinite value is lost in the following language formation stages (35).

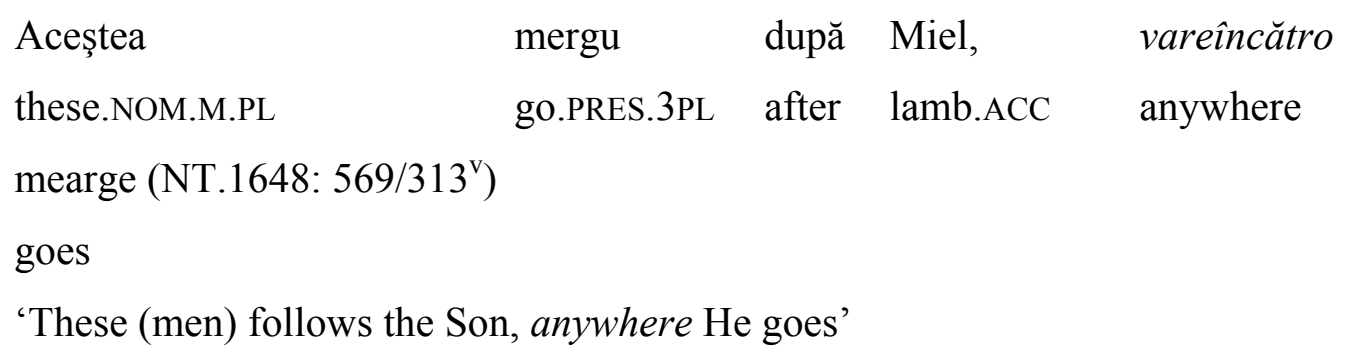

As in the case of pro-nouns, the pro-adverbs can function also as relative connectors, introducing various types of subordinate clauses: locative clause (36), time clause (37) and concessive clause (38).

$\begin{array}{lllll}\text { Invățătoriule, } & \text { mearge-voiu } & \text { după } & \text { Tine, } & \text { vareunde } \\ \text { master.VOC } & \text { follow.INF=AUX.FUT.1SG } & \text { after } & \text { You.ACC } & \text { anywhere } \\ \text { vei } & \text { mearge (NT.1648: 132/10 } & & & \\ \text { AUX.FUT.2SG } & \text { go.INF } & & & \end{array}$

'Master, I will follow You, anywhere You go.'

\begin{tabular}{|c|c|c|c|}
\hline Spre & Domnul & nădăjduit & Oricând \\
\hline to & God.ACC & AUX.PERF.1SG hope.PPLE & any.time \\
\hline & fost & scârbit (DPV.1673 & \\
\hline
\end{tabular}

AUX.PERF.1SG be.PPLE

disgust.PPLE.M.SG

'I put my faith in God / Any time I was disgusted'

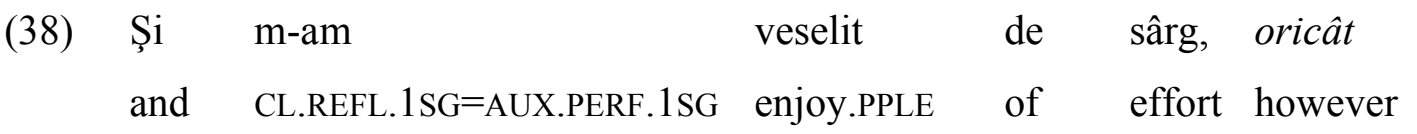




$\begin{array}{llll}\text { mi-au } & \text { fost } & \text { de } & \left.\text { rău (DPV.1673: 153 }{ }^{\mathrm{r}}\right) \\ \text { CL.DAT.1SG=AUX.PERF.3SG } & \text { be.PPLE } & \text { of } & \text { hard }\end{array}$

'And I was cheerful, however hard it was'

Considering the veri- series, we identified in the corpus only the pro-adverbs: veriunde (39), and vericât (40), used exclusively as connectors:

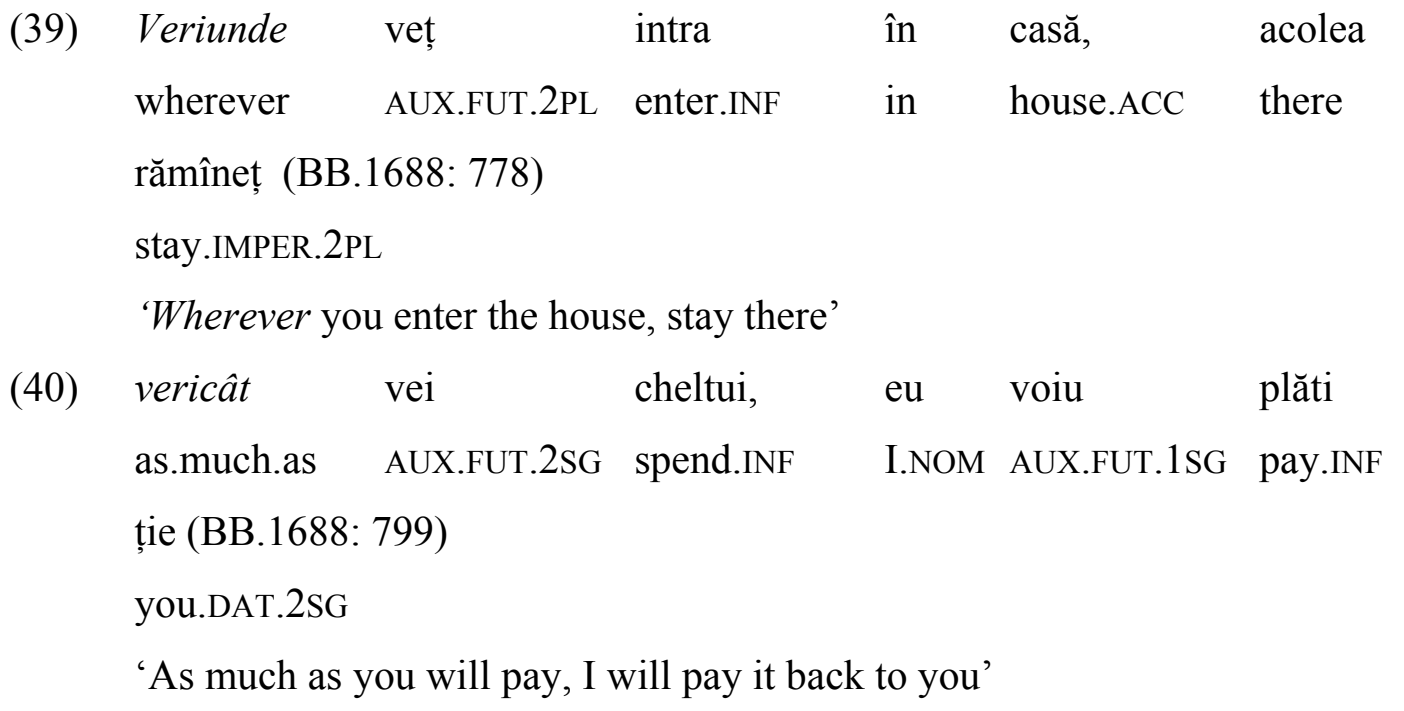

\subsection{Modern Romanian language $\left(19^{\text {th }}-20^{\text {th }} \mathrm{c}\right.$.}

According to SILR, the situation of the pro-forms in Modern Romanian was slightly different from the previous stage investigated.

4.2.1. Indefinite pro-nouns, also used in some contexts as pro-adjectives and connectors As far as the indefinite pro-nouns and pro-adjectives are concerned, the authors of SILR noticed that the use of the ori- series (oricine, orice, oricare, oricât) has been generalized in the $19^{\text {th }}$ century. The pro-noun oricare, identified in the previous stage as having variable uses, keeps its variability at the beginning of the century, but the unmarked forms prevail during the entire century. Thus, the forms oricarea, oricarii disappear and oricarele is rarely used.

Considering the oare- series, it can be noticed that the form oarecare is widely employed during the entire century, while the forms oarecine, and oarece are rarely 
used. As in the case of oricare, the pro-noun oarecare is used invariable in most contexts.

The situation regarding the interposing of prepositions in the indefinite structure, observed in the previous stage, continues at the beginning of the $19^{\text {th }}$ century, as in the following examples extracted from the reference volume.

$\begin{array}{llllll}\text { Mărturisim } & \mathrm{cu} & \text { cuget } & \text { curat ori la ce } \\ \text { confess.PRES.1PL } & \text { with } & \text { soul.ACC } & \text { pure any in what trial } \\ \text { judecată... } & & & & & \\ \text { trial } & & & & \end{array}$

'We confess sincerely in any trial...'

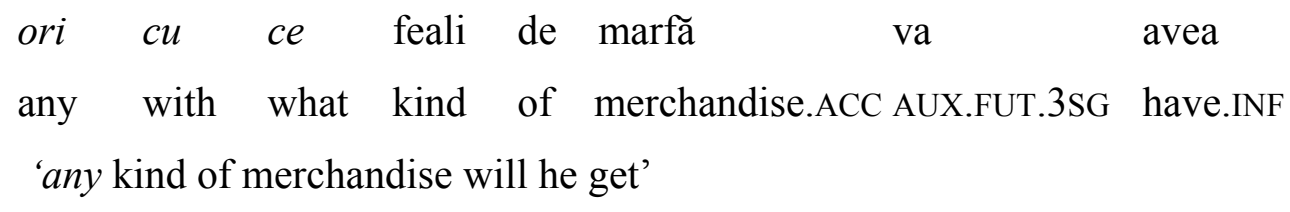

Although the authors of this volume state that the indefinite pro-forms compound with veri- are attested at the beginning of the $19^{\text {th }}$ century in Muntenia (vericare, verice), but also in Moldova (verice, verce), the analysis of the Old Romanian corpus revealed the presence of the veri- series as early as the 17th century (BB.1688). The grammars of the first half of the $20^{\text {th }}$ century record the forms vericare, vericine, verice as obsolete.

Another aspect specific to this language stage is represented by the occurrence of fewer and fewer cases of prepositions interposed in the compound structures:

$\begin{array}{llll}\text { Ori pe } & \text { ce loc } & \text { işi } & \text { aşază } \\ \text { Any on } & \text { what place.ACC } & \text { CL.DAT.3SG } & \text { settle.PRES.3SG } \\ \text { omul } & \text { cultul. } & \\ \text { man.DEF.NOM religion.DEF.ACC } & \\ \text { 'In any place the man settles his religion' } & \end{array}$

In the $20^{\text {th }}$ century, the form oricine functions only as a pro-noun:

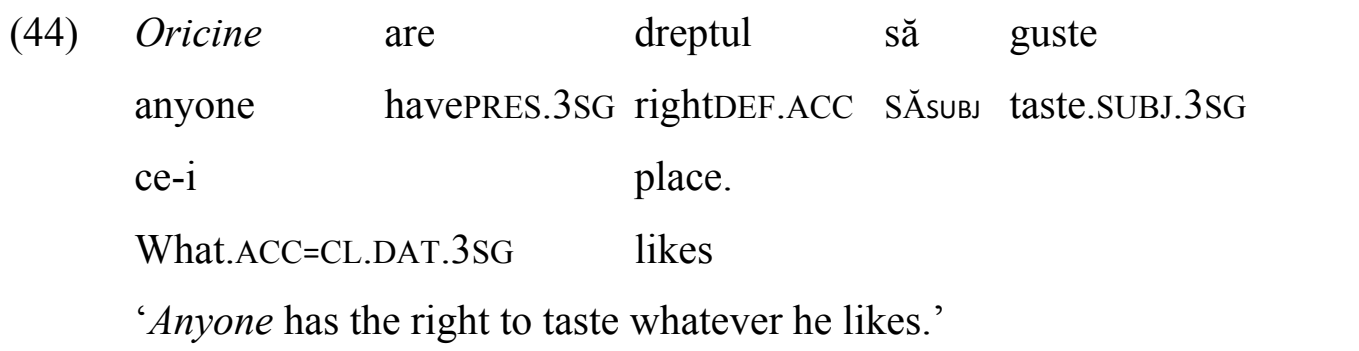


On the other hand, orice can take a double function, pronominal (mostly when used as a concessive connector (45)) and adjectival.

$\begin{array}{llllll}\begin{array}{l}\text { Orice } \\ \text { anything }\end{array} & \text { AUX.FUT.3SG } & \text { say.INF } & \text { Church.DEF.NOM } & \text { de } & \text { Apus, } \\ \begin{array}{l}\text { lucrurile } \\ \text { stau }\end{array} & \text { aşa } & & \text { West } \\ \text { things.DEF.NOM } & \text { stay.PRES.3PL like.this } & \\ \text { 'Things stay as they are, no matter what the Western Church says' }\end{array}$

More and more frequently, the form orice appears in quasi-fixed structures, such as:

\begin{tabular}{|c|c|c|}
\hline Orice & s-ar & zice \\
\hline anything & $\mathrm{CL} \cdot \mathrm{REFL}=\mathrm{AUX} \cdot \mathrm{COND} \cdot 3 \mathrm{SG}$ & say.INF \\
\hline
\end{tabular}

A peculiar situation is the one in which orice is used with a noun in the plural, situation considered noncompliant with the Romanian grammar norms: chei pentru orice sertare ('keys for any drawers').

The $20^{\text {th }}$ century texts reveal the possibility of combining the pro-adjective orice/oricare with another indefinite form as: alt, altceva, in order to intensify the indefinite value. In the first two decades of the century the construction is rare (orice alt cetățean ['any other citizen']), and it starts to increase in number after 1930 (orice altceva ['anything else']). Comparing this situation with the one found in OR, we can underline the difference in topic preference of the indefinite form alt, located in front of the indefinite pro-form, as in (10).

\subsubsection{Pro-adverbs and connectors}

Among the pro-adverbs, the oare- series is more frequently used than the ori-, oarecum being the form most used within the series. Adding to the forms vareincotro/oareincătruo specific to the old language, we can notice in this period the presence of the form ori încătro:

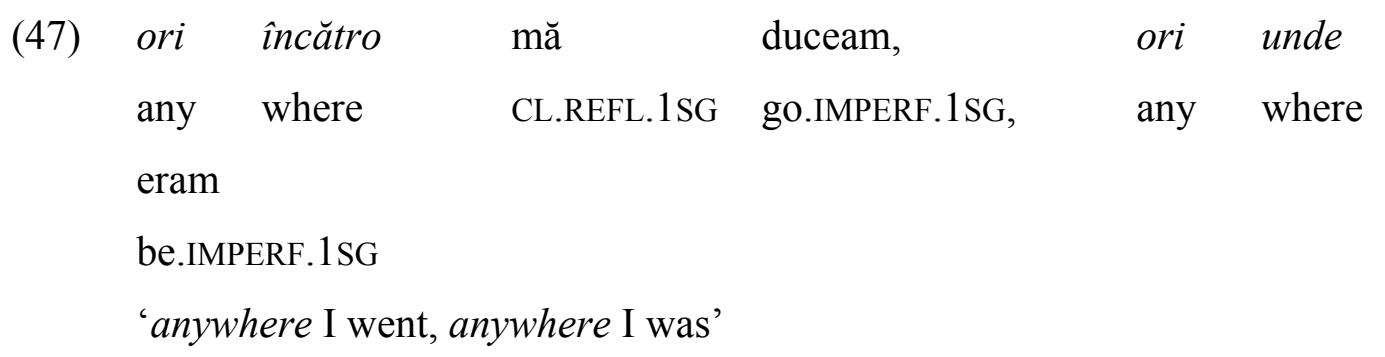


So, based on the comparison of the two major periods (OR and MR), we conclude that, beyond the variation of the formal aspects of these pro-forms, the morphosyntactical uses remain, mainly, the same.

4.3. The Present-Day Romanian language $\left(21^{\text {st }} \mathrm{c}\right.$.)

4.3.1. Indefinite pro-nouns, also used in some contexts as pro-adjectives and connectors

From a semantic point of view, these pro-forms are considered to be indefinite quantifiers, as they do not offer information on the exact quantity, but only some hints regarding the part-and-whole relation (GALR 2008: 253). Basically, the quantifiers formed with cine refer to entities having the [+ Human] semantic value (48.a) while the ones compound with ce refer to entities having the [-Human, - Animate] semantic values (48.b).

(48a) Oricine poate face asta

anybody can.PRES.3SG do.INF this.ACC

'Anyone can do this'

(48b) $\mathrm{Ar}$

face orice pentru bani

AUX.COND.3SG do.INF anything for money.ACC

'He would do anything for money'

The pro-forms with care refer to entities having the [+/- Human, +Anaphoric] semantic values:

\begin{tabular}{|c|c|c|}
\hline Oricare & dintre cele / cei & prezentate/ prezentați \\
\hline Any.NOM & those.F/M.PL sh & PLE \\
\hline te-ar & putea & interesa \\
\hline CL.ACC.2.S & AUX.COND.3.SG can.INF & interest.INF \\
\hline
\end{tabular}

The ones compound with cât/câtă refer to entities having the [+Quantitative,Countable] semantic values (50a) while the ones with câți / câte imply entities with [+Quantitative, +Countable] semantic value (50b) 
(50a) Oricâtă înghețată primește, tot mai vrea Any.F.SG ice.cream.ACC get.PRES.3.SG still more wants

'No matter how much ice cream he gets, he still wants more'

(50b) Oricâte bomboane primeşte, tot mai vrea any.how.much.F.PL candies.ACC gets still more wants

'No matter how many candies he gets, he still wants more.'

As seen in the previous stages of Romanian, the indefinite pro-nouns can recategorize to nouns with the meaning "unknown person" (51a-b)

(51a) $\mathrm{Nu}$ e un oarecare, ci e un mare doctor Not is a someone, but is a great doctor.NOM

'He is not just someone; he is a well-known doctor'

(51b) Întru aceale zile să născu un oarecarile, in those days.ACC CL.REFL be.born.PS.3.SG a someone.DEF numele $\quad$ lui $-\quad$ Noe (MPI. $\sim$ middle of the $17^{\text {th }}$ c.: $8^{\mathrm{v}}$ ) name.DEF.NOM his.GEN Noah

'Those days, someone was born, his name - Noe.'

In post-position, the indefinite pro-adjective oarecare gets the qualificational meaning „ordinary” (52a), situation that appears as early as the 17th century (52b):

(52a) E $\quad$ o studentă oarecare (GBLR 2010: 153)

(She)is a student.NOM any.which

'She is an ordinary student'

$\begin{array}{llll}\text { Om } & \text { oarecarele } & \text { era } & \text { in țara } \\ \text { man.NOM } & \text { ordinary } & \text { be.IMPERF.3.SG } & \text { in country.DEF.ACC } \\ \text { Avsitidii, } & \text { căruia } & \text { era } & \text { numele } \\ \text { Uz.DEF.GEN } & \text { who.GEN.M.SG be.IMPERF.3.SG } & \text { name.DEF.NOM } \\ \text { Iov (BB.1688:362) } & \\ \text { Job.NOM } & \\ \text { 'There was an ordinary man in the land of Uz, whose name was Job' }\end{array}$

The indefinite pro-forms can be used in expressing pragmatic strategies approximation (53a), attenuation (53b) and empathizing (53c) with the interlocutor: 
(53a) Există oaresce reticențe

Exists some reluctances.NOM

'There are some reluctances.'

(53b)

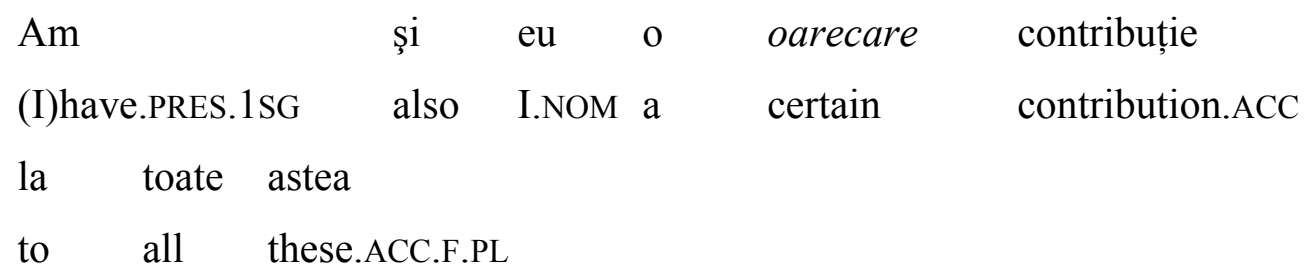

'I do have a certain contribution to all these'

(53c) Ai făcut şi tu oarece prostiuțe pe AUX.PERF.2.SGdo.PPLE also you.NOM some follies.ACC on acolo, nu? there not

'You did some follies there too, didn't you?' (GALR 2008: 268)

In Present-Day Romanian, a distinction has been made between the uses of the proadverbs: indefinite (modal), relative and others (GBLR 2010: 312), as seen in the following examples (54-57):

Adverb

(54) Se îmbracă oricum

CL.REFL.ACC dresS.PRES.3SG anyway

'She dresses anyway'

Modal indefinite adverb+relative

Se îmbracă
CL.REFL.ACC dress.PRES.3SG aric
cere
ask.PRES.3SG
'She dresses in any way she is requested'

Modal indefinite adverb + relative + concessive

$\begin{array}{llllll}\text { Oricum } & \text { ai } & \text { proceda, } & \text { nu } & \text { procedezi } & \text { bine } \\ \text { whatever } & \text { AUX.COND.2SG } & \text { do.INF } & \text { not } & \text { do.PRES.2SG } & \text { right }\end{array}$

'Whatever you do, you are not doing it right' 
Modal indefinite adverb+discourse marker

$\begin{array}{lllll}\text { Oricum, } & \text { guvernanții } & \text { nu } & \text { iau } & \text { nicio măsură } \\ \text { anyway } & \text { guvernants.DEF.NOM } & \text { not } & \text { take.PRES.3.PL any } & \text { action.ACC }\end{array}$

'The guvernants are not taking any actions, anyway.'

4.4. The grammaticalization and pragmaticalization of the Romanian indefinite proforms

\subsubsection{General considerations}

Based on etymological considerations (see 2.1), we developed the following theory concerning the grammaticalization paths of the indefinite pro-forms: vare (interrogative particle) + pro-noun/adverb $>$ vare $($ indefinite proclitic element $)+$ pro-noun/adverb $>$ oare (interrogative particle/indefinite proclitic element) + pro-noun/adverb $>$ ori (indefinite proclitic element) + pro-noun/adverb.

The steps within the grammaticalization path cannot be clearly distinguished, as in the first texts attested for the Romanian language $\left(16^{\text {th }} \mathrm{c}\right.$.) all these forms coexist with all the functions above mentioned. The verbal origin of the interrogative particle vare (VOLET) has already been established by previous research on grammaticalization (Dinică and Zamfir 2009), while the interrogative source of the indefinite proclitic element vare has been well-argumented (Haspelmath 1997). In addition, we consider that this grammaticalization step from the Old Romanian language has been possible due to the morphosyntactic association of the interrogative particle with an interrogative pro-noun (cine, ce). Later on, vare loses its interrogative meaning, starting the univerbation process of the indefinite pro-forms. The process had several stages of grammaticalization: in the first period, the two elements were unbound (vare ce, vare cine, vare care), allowing the interpositioning of a preposition (see examples 41 and 42 above), and it evolved through the stage of a bound indefinite pronoun (varece, varecine, varecare). 
4.4.2. Case study - the grammaticalization scenario of the indefinite pro-noun oarece/orice

vare $($ interrogative particle) $>$ vare (indefinite proclitic element $)+c e$ (relative pronoun) $>$ (indefinite pro-form, vare ce/varece/vare prep. ce) $>$ oare (interrogative particle/indefinite proclitic element) $+c e$ (relative pronoun) (indefinite pro-form, oare ce/oarece/oare prep. ce) $>$ ori $+c e$ (indefinite pro-form, orice, ori prep. ce)

First, we will focus on the essential mechanisms used in grammaticalization, on the primitive changes that occur and on the possible side effects of the process, and then we will comment on the linguistic status (i.e. lexical, grammatical or communicative) and stages of grammaticalization of the Romanian indefinite pro-form orice.

The first step in the development of orice is represented by the reanalysis of the futuretense auxiliary vare into the indefinite element oare. Once the indefinite status has been established, oare agglutinated to $c e$ and developed into orice, due to some phonetic reasons, cf. the examples in Section 4.1. The other gradual evolution of orice - from the subjunctive verbal form veri into the disjunctive connector ori, and then into the indefinite pro-noun orice - occurred probably simultaneously and closely influenced by these forms already used in the Old Romanian language.

Semantically, there are contiguous, metonymic relations between the various interrogative (58), disjunctive (59), indefinite (60) and concessive (61) meanings of vare/oare/ori(ce), all being nuances in the domain of doubt/uncertainty and approximation.

$\begin{array}{lll}\text { cugeta } & \text { oare ce ară } & \text { fi } \\ \text { think.IMPERF.3SG } & \text { INT what AUX.COND.3.SG } & \text { be.INF } \\ \text { închinarea } & \left.\text { aceaia (NT.1648:212/66 }{ }^{\mathrm{r}}\right) & \\ \text { offer.DEF.NOM } & \text { that } & \end{array}$

'she was thinking what that offer may be'

\begin{tabular}{|c|c|c|c|c|c|}
\hline Noi & toți & ne-am & & botezat; & jidovi, \\
\hline we & all & CL.REFL. $1 \mathrm{PL}=$ & AUX.PERF.1PL & bapthize.PPLE & Jews \\
\hline vare & grecii, & vare & slugile, & slobozi & iii. (NT.1648: 450/234 ${ }^{\mathrm{r}}$ ) \\
\hline or & Greeks &. $\mathrm{DEF}$ & slaves.DEF & free.me & en.DEF \\
\hline
\end{tabular}


$(60)$

\begin{tabular}{|c|c|c|c|c|c|}
\hline Cest & fecior & du-1 & & cătră & muiare \\
\hline this.M.SG & boy.ACC & take.IMP. $2 \mathrm{sG}=$ & M.SG & to & woman.ACC \\
\hline are & oarece & spune & lui! (C & $\operatorname{Pr} .156$ & $: 113)$ \\
\hline has & something & tell.INF & he.DA & T.M.SG & \\
\hline
\end{tabular}

'Take this boy to the woman, as she has something to tell him!'

$\begin{array}{lllll}\text { Şi toate } & \text { rabdă, } & \text { oarece- } \mathrm{i} & \text { fac } \\ \text { and } & \text { all } & \text { endure.PRES.3SG } & \text { anything=CL.DAT.M.SG } & \text { do.PRES.3PL }\end{array}$

(FD.1592-1604: 598 ${ }^{\mathrm{v}}$ )

'And he endures all, no matter what they do to him'

The pro-form oarece is used in the $16^{\text {th }} \mathrm{c}$., both with quantitative (indefinite and universal) and non-quantitative indefinite meaning, as in: puțină oarece împărțitură indefinite quantifier ('some'); tot oarece - universal quantifier ('everything') and oarece lucru bun - free-choice indefinite pro-adjective ('any').

In the Present-Day Romanian language, the quantificational meaning of oarece is blurred, and the $[+$ indefinite $]$ inherent feature moves towards discursive values (attenuation) (see 62), in order to mitigate the relation between the interlocutors (Vasilescu 2009: 152):

$\begin{array}{lllll}\text { Am } & \text { oarece îndoieli } & \text { în } & \text { legătură } & \text { cu } \\ \text { (I) have.PRES.1SG } & \text { some doubts.ACC } & \text { in } & \text { concern } & \text { to } \\ \text { veridicitatea } & \text { cuvintelor } & \text { tale } & \\ \text { truthfulness.DEF.ACC } & \text { words.DEF.GEN } & \text { your.GEN } \\ \text { 'I have some doubts concerning the truthfulness of your words' }\end{array}$

The primitive changes that accompany the formal reanalysis and semantic reinterpretation are represented by the features described in Section 3.2. At the phonetical level, there is some loss of phonological/phonetic substance in the development of the Romanian orice from voare/oarece (see 2.1). In addition, one may notice some changes in the morphological compositionality, since orice is a compositional form, and its internal structure was affected by reduction: oare $+c e>$ orice.

We also notice the loss of morphosyntactic properties due to the shift form indefinite pro-noun to indefinite pro-adjective. The use in the Present-Day Romanian language of 
orice as pro-form and sentence connector results in a loss of syntactic variability (the fixation of the pro-adjective in prenominal position) and autonomy (does not allow interpositioning) of the indefinite orice. In extension, orice starts to be employed more frequently in quasi-phrasal structures (Chivu et al. 2012:517), such as: orice s-ar zice ('whatever they say'), orice s-ar intâmpla ('whatever it may happen') or it allows the combination with another indefinite pro-form: orice altceva aş fi făcut ('anything else I would have done'). As far as the semantic changes are concerned, the data revealed a more bleached meaning of orice. It increasingly develops various nuances in the realm of indefiniteness.

As far as orice is concerned, the side effects are noticeable. Paradigmaticization ${ }^{7}$ is generally related to productivity and frequency, all being correlated in the development of orice. In a general sense, orice enters the indefinite pro-noun paradigm, and is a frequent linguistic item. Obligatorification (decrease of paradigmatic variability (Beijering 2012: 48)) clearly does not apply to orice as it is a free choice element, exception being the concessive connector status. Likewise, condensation ${ }^{8}$ does not occur because the structural scope of orice is not reduced.

With respect to layering, we see that the interrogative particle vare(ce) was reanalysed as the indefinite proclitic element ori(ce). The indefinite pro-form ori can be used to express various dimensions of indefiniteness. It may be used as a relative/concessive sentence connector, or it may occur in set phrases. As regards divergence ${ }^{9}$, it can be observed that the source of ori(ce), the interrogative form vare(ce) continued to exist in the $16^{\text {th }} \mathrm{c}$. along with the new indefinite form. Specialization does not apply to orice, as similar and simultaneously existing expressions are not reduced to one major expression. Persistence relates to the observation that a linguistic item or construction retains traces of the linguistic item or construction from which it emerged. In the second

\footnotetext{
${ }^{7}$ Paradigmaticity is defined as The cohesion of a sign with other signs in a paradigm,(...) that is, the degree to which it enters a paradigm, is integrated into it and dependent on it. (Beijering 2012: 42)

${ }^{8}$ As defined by Beijering 2012: 108, condensation represents a decrease in syntactic scope, but also an increased dependency.

${ }^{9}$ When a lexical form undergoes grammaticization to clitic or affix, the original lexical form may remain as an autonomous element and undergo the same changes as ordinary lexical items. ( Beijering 2012: 44)
} 
stage of the grammaticalization process, oare(ce) retains the properties of the interrogative particle vare, but these properties are lost in the case of the indefinite ori(ce).

In conclusion, the patterns show that the development of orice has most properties in common with secondary grammaticalization.

4.4.3. Case study - the grammaticalization and pragmaticalization of the indefinite proadverb oricum

vare (interrogative particle) $>$ vare (indefinite proclitic element) + cum (relative adverb) (indefinite pro-form, vare cum/varecum) > oare (interrogative particle / indefinite proclitic element) + cum (relative adverb) (indefinite pro-form, oarecum) $>$ ori + cum (indefinite pro-form, oricum)

We focus next on the essential mechanisms used in grammaticalization and pragmaticalization, on the primitive changes that occur and on the possible side effects of the process, and then we concentrate on the linguistic status and stages of grammaticalization and pragmaticalization of the Romanian indefinite pro-form oricum. The development of oricum has as its initial stage the reanalysis of the future-tense auxiliary vare into the indefinite element oare. Once the indefinite status has been established, oare agglutinated to cum and developed into oricum, due to phonetic reasons, cf. the examples in Section 4.1.

Based on the examples extracted from the corpus, we established the following grammaticalization path, in which the last stage is considered to be pragmaticalization: oare(cum) - interrogative adverb (63) > oare(cum)/ori(cum) - indefinite pro-adverb (64) $>$ oarecum/oricum - sentence connector (65) > oricum - discourse marker (66)

Oare cum să vinde acel lemnu ce INT how CL.REFL sells that.M.SG miroseşte? (Sind. 1703:113v) smells

'- How does the smelling wood sell?' 
(64)

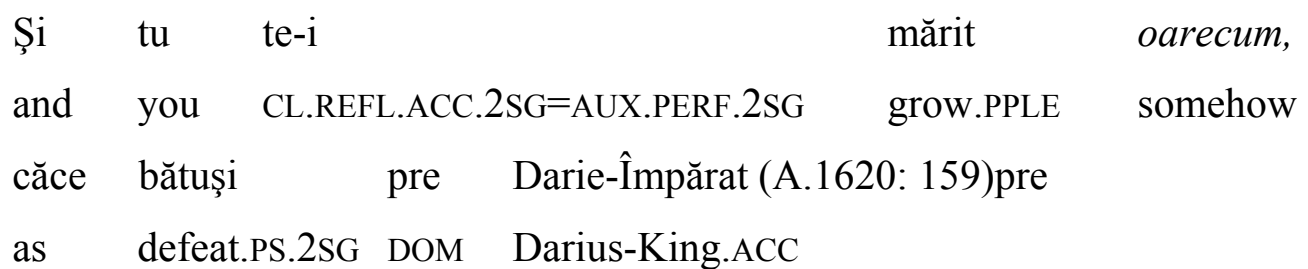

as defeat.PS.2SG DOM Darius-King.ACC

'And your kingdom grew somehow, as you defeated King Darius'

(65)

oricum vei vrea, Stăpâne, piiarde-ne

anyway AUX.FUT.2SG want.INF Lord.vOC

piiarde-ne pre noi (Biblia Blaj: 10)

kill.IMP.2SG=CL.ACC.1PL DOM us

'Do whatsoever you want with our lives'

(66)

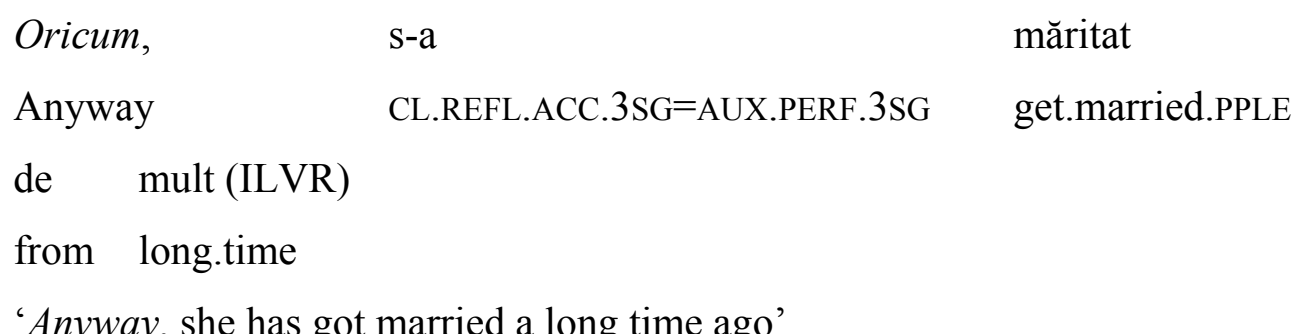

The primitive changes that accompany the formal reanalysis and semantic reinterpretation are explained below: at the phonetical level, there is some loss of phonological/phonetic substance in the development of the Romanian oricum from varecum/oareceum (see 2.1). In addition, one may notice changes in morphological compositionality, since oricum is a compositional form, its internal structure being affected by reduction: oare + cum $>$ oricum.

We also notice the loss of morphosyntactic properties, due to the shift form interrogative adverb vare/oare to indefinite proclitic element oare/ori. The use of oricum as a pro-adverb and sentence connector in Present-Day Romanian results in loss of syntactic variability (the adjectival use of these forms in Old Romanian language is lost). In extension, oricum starts to appear more in quasi-phrasal structures, such as: oricum ar fi.

As far as the semantic changes are concerned, oricum has a more bleached meaning, developing various nuances in the realm of indefiniteness and modality: cumva ('somehow'), intr-o oarecare măsură ('to some extent'), în orice fel ('in any way'), măcar ('at least'). 
Paradigmaticization is generally related to productivity and frequency, all being correlated in the development of oricum. In a general sense, oricum enters the indefinite pro-adverb paradigm, and is a frequent linguistic item. Obligatorification clearly does not apply to oricum as it is a free choice element, exception being the concessive connector status. Likewise, condensation does not occur because the structural scope of oricum is not reduced, nor does it become (more) dependent upon other constituents in the clause, rather the opposite. That is, sentence adverbs are integrated into syntactic structures, but flexible with regard to their positions.

With respect to layering, the data show instances of coexistence of both adverbial and subordinating oricum. The older oricum (with indefinite pro-adverbial properties) still exists along with the newer oricum that functions also as a sentence connector. As for the divergence, it can be noticed that the source of ori(cum) - the interrogative form vare(cum) - continued to exist in the OR besides the new indefinite form. Specialization does not apply to oricum, as similar and simultaneously existing expressions are not reduced to one major expression. Persistence relates to the fact that a linguistic item or construction retains traces of the linguistic item or construction from which it emerged. In the second stage of the grammaticalization process, oare(cum) retains the properties of the interrogative particle vare, but these properties are lost in the case of the indefinite ori(cum).

The pragmaticalization of the indefinite pro-adverb oricum implies hierarchical reanalysis, meaning the shift from a propositional (67) to an extra-propositional (68) status, and reinterpretation from relational to communicative meaning.

$\begin{array}{lllll}\text { Oricum } & \text { să } & \text { fie } & \text { fost } & \text { tălmăcirea } \\ \text { anyhow } & \text { SĂ } & & \\ \text { aceasta, } & \text { AUX.SUBJ } & \text { be.PPLE } & \text { translation.DEF.NOM } \\ \text { aceasta } & \text { cu } & \text { adevărat } & \text { să } & \text { ştie this.F.SG } \\ \text { this.F.SG } & \text { this.NOM.F.SG with } & \text { truth } & \text { CL.REFL } & \text { knows } \\ \text { (Biblia Blaj, Cuvânt înainte) } & & & \\ \text { 'No matter how this translation was made, it is certain that this was done way } \\ \text { before Christ had come' }\end{array}$




$\begin{array}{llllll}\text { Oricum, } & \text { mă } & \text { ajută } & \text { cineva } & \text { să } & \text { scriu, } \\ \text { anyway } & \text { CL.ACC.1SG } & \text { helps } & \text { somebody } & \text { SĂ.SUBJ } & \text { write.SUBJ.1SG } \\ \text { că } & \text { eu } & \text { nu } & \text { lucrez } & \text { la } & \text { calculator (ILVR) } \\ \text { as } & \text { I.NOM } & \text { not } & \text { work.PRES.1SG } & \text { on } & \text { computer.ACC }\end{array}$

'Anyway, somebody will write it for me, I do not use computers, so I will hire somebody'

The primitive changes triggered by pragmaticalization manifest at semantic (bleaching) and discourse (increased speaker-perspective, attitude or judgment (subjectification) and attention to speaker-addressee interaction (intersubjectification)) levels. The side effects of the pragmaticalization of oricum result in layering and specialization, context expansion and increased frequency.

In conclusion, the patterns show that the development of oricum has most properties in common with secondary grammaticalization and pragmaticalization.

\section{Final considerations}

The purpose of this article was to describe the pragma-linguistic scenario that accounts for the actual situation of the Romanian indefinite compounds. After briefly presenting the current problematic situation of the etymology of the Romanian indefinite proforms, we described the main tenets of grammaticalization and pragmaticalization theories, underlining the perspective given by Beijering (2012) who offers quite a novel theoretical frame. The actual analysis focused on the semantic meanings, morphosyntactic and pragmatic functions taken by these forms during the grammaticalization /pragmaticalization paths: vare (interrogative particle) + pronoun/adverb $>$ vare (indefinite proclitic element) + pro-noun/adverb $>$ oare (interrogative particle/indefinite proclitic element) + pro-noun/adverb $>$ ori (indefinite proclitic element) + pro-noun/adverb.

The analysis of the data (comprising texts from $16^{\text {th }}-21^{\text {st }}$ centuries) has shown that the grammaticalization (that started from the Common Daco-Romanian stage of language formation as mentioned by different researchers) and pragmaticalization processes of the Romanian indefinite pro-forms continued and finalized in the Present-Day Romanian language. 
Sources and acronyms

A.1620 -“Alexandria”, ed. F. Zgraon, București, Fundaţia Naţională pentru Ştiinţă şi Artă, 2005 (Cele mai vechi cărți populare în literatura română, 11).

AA.1708 -“Archirie şi Anadan”, ed. Magdalena Georgescu, Bucureşti, Minerva, 1997 (Cele mai vechi cărți populare în literatura română, II), 157-68.

AAM.1713 - Antim Ivireanul, Opere, ed. G. Ştrempel, Bucureşti, 1997.

AD.1722-5 - Antim Ivireanul, Didahii. ed. Antim Ivireanul, Opere, ed. G. Ştrempel, Bucureşti, 1997, 3-210.

AIS.1705 - Antim Ivireanul, "Învăţătură pe scurt pentru taina pocăinţii”, ed. Antim Ivireanul, Opere, ed. G. Ştrempel, Bucureşti, 1997, 303-19.

BB.1688 - Biblia (Bucureşti), ed.Biblia adecă Dumnezeiasca Scriptură a Vechiului şi Noului Testament, Patriarhul Bisericii Ortodoxe Române, Bucureşti, 1977.

Bert.1774 -“Bertoldo”,ed. Magdalena Georgescu, Bucureşti, Minerva, 1999, (Cele mai vechi cărți populare în literatura română, III), 157-239.

Biblia Blaj - Biblia de la Blaj, 1795, bitflow.dyndns.org/romanian/Biblia/RomanianBiblia_Blaj_1795.pdf.

CC1.1567-8 - Coresi, "Tâlcul Evangheliilor", ed. Coresi, Tâlcul evangheliilor şi molitvenic românesc, ed. V. Drimba, Bucureşti, Editura Academiei, 1998, 31-187.

CM.1567-8 - Coresi, "Molitvenic",ed. Coresi, Tâlcul evangheliilor şi molitvenic românesc, ed. V. Drimba, Bucureşti, Editura Academiei, 1998, 189-211.

CPr. 1566-7 - Coresi, “Apostol”,ed. I. Bianu, Texte de limbă din secolul XVI, IV, Lucrul apostolesc tipărit de diaconul Coresi la 1563, Bucureşti, 1930.

DÎ - Documente şi însemnări româneşti din secolul al XVI-lea, ed. Gh. Chivu, M.Georgescu, M. Ioniță, Al. Mareş, Al. Roman-Moraru, Bucureşti, Editura Academiei Române, 1979.

DPV.1673 - Dosoftei, Psaltirea în versuri (Uniev), ed.: Dosoftei, Opere, 1, Versuri, ed. N. A. Ursu, Iaşi, 1974.

Fil. ante 1837 - "Istoriia lui Filerot cu Antusa", ed. Nicolae Cartojan, Bucureşti, EER, 1974 (Cele mai vechi cărți populare în literatura română, II). 
FD.1592-1604 -“Floarea darurilor”, ed. Alexandra Roman Moraru, Bucureşti, Minerva, 1996 (Cele mai vechi cărți populare, I), 119-82.

ILVR - Interacțiunea verbală în limba română actuală. Corpus (selectiv). Schiță de tipologie, Ionescu-Ruxandoiu, Liliana, Editura Universităţii din Bucureşti, 2002

MPI. $\sim$ middle of the $17^{\text {th }}$ c. - "Palia istorică", ed. A. Roman Moraru, M. Moraru, Bucureşti, Fundația Națională pentru Ştiință şi Artă, 2001 (Cele mai vechi cărți populare în literatura română, IV).

NT.1648 - Noul Testament (Bălgrad/Alba Iulia), ed. Alba Iulia, 1998

PH.1500-10 - Psaltirea Hurmuzaki, ed. I. Gheție i Mirela Teodorescu, Bucure ti, Editura Academiei Române, 2005.

PO. 1582 - Palia de la Orăştie, ed. V. Pamfil, Bucure ti, Editura Academiei Române, 1968.

Prav.1581 - Pravila ritorului Lucaci, ed. I. Rizescu, Bucureşti, Editura Academiei RSR, 1971.

Sind.1703 - "Sindipa”, ed. Magdalena Georgescu, Bucureşti, Minerva, 1996 (Cele mai vechi cărți populare în literatura română, I), 249-315.

\section{References}

Aijmer, Karin. 2013. Understanding Pragmatic Markers: A Variational Pragmatic Approach, Edinburgh: Edinburgh University Press.

Aijmer, Karin. 1997. 'I think' - an English modal particle. In Toril Swan and Olaf J. Westvik (eds.), Modality in Germanic languages. Historical and comparative perspectives. 1-47. Berlin/New York: Mouton de Gruyter.

Beijering, Karin. 2012. Expressions of epistemic modality in Mainland Scandinavian. A study into the lexicalization-grammaticalization-pragmaticalization interface. The Netherlands: Wöhrmann Print Service, Zutphen.

Brinton, Laurel and Elizabeth Traugott. 2005. Lexicalization and Language Change. Cambridge: Cambridge University Press. 
Bybee, Joan L. 2003. "Cognitive processes in grammaticalization”. In Michel Tomasello (ed.), The New Psychology of Language, Volume II., 145-167. New Jersey: Lawrence Erlbaum Associates Inc.

Candrea, I. A. and Ovid Densusianu. 1914. Dicționarul etimologic al limbii române. [The Etymological Dictionary of Romanian Language] Bucureşti: Librăria Socec \& Comp.

Chivu, Gheorghe. Pană Dindelegan, Gabriela, Dragomirescu, Adina, Nedelcu, Isabela and Nicula Irina. (eds.) 2012. Studii de Istorie a Limbii Române (Morfosintaxa limbii literare în secolele al XIX-lea şi al XX-lea). [Historical Studies of Romanian language (The morphosyntax of the literary language in the 19th and 20th centuries)] Bucureşti: Editura Academiei Române.

Dahl, Östen. 2005. Indefinite pronouns. In Keith Brown (ed.), Encyclopedia of Language \& Linguistics. 588-590. Oxford: Elsevier.

Diewald, Gabriele. 2011. Pragmaticalization (defined) as grammaticalization of discourse functions. Linguistics, 49(2), 365-390.

Dimitrescu, Florica. 1974. Introducere în morfosintaxa istorică a limbii române. [Introduction to the hystorical morphosyntax of Romanian language] Bucureşti: Editura Universității.

Dinică, Andreea, Zamfir, Dana-Mihaela. 2009: Quelques cas de grammaticalisation des formes flexionnelles du verbe a vrea ,vouloir” en vieux daco-roumain: les conjonctions et locutions conjonctionnelles disjonctives et concessives (să) veri (că) „ou; soit; soit même; bien que”, săva(i) (că) ,idem”. Available at: http://www.unibuc.ro/ro/zamfir_dinica2009_ro (accessed on August 2014)

Erman, Brit, Kotsinas, Ulla-Britt. 1993. Pragmaticalization: The case of 'ba' and you know. Studier i modern spríkvetenskap. 76-93. Stockholm: Almqvist and Wiksell,.

Guțu Romalo, Valeria. (ed.) 2008. Gramatica limbii române, I, Cuvântul, II, Enunțul. [The Romanian language grammar. I - the word, II - the sentence] Bucureşti: Editura Academiei.

Haspelmath, Martin. 1997. Indefinite Pronouns. Oxford: Oxford University Press. 
Hopper, Paul J. 1991 On some principles of grammaticization. In Elizabeth Closs Traugott and Bernd Heine (eds), Approaches to grammaticalization, volume I. 1735. Amsterdam: John Benjamins.

Krieb-Stoian, Silvia. 2011. Mijloace lingvistice de realizare a aproximării în limba română. [Linguistic methods for creating approximation in Romanian language] Bucureşti: Editura Universității Bucureşti.

Lehmann, Christian. 2002. Thoughts on Grammaticalization. Vol. 2. (revised edition). (Arbeitspapiere des Seminars für Sprachwissenschaft der Universität Erfurt, No. 9. Erfurt.

Pană Dindelegan, Gabriela, Dragomirescu, Adina, Nedelcu, Izabela (eds.) 2010. Gramatica de bază a limbii române. [The basic grammar of Romanian language] Bucureşti: Editura Univers Enciclopedic Gold.

Pană Dindelegan, Gabriela. (ed.) 2013. The Grammar of Romanian. Oxford: Oxford University Press.

Rosetti, Alexandru. 1968. Istoria limbii române. [The history of Romanian language] Bucureşti: Editura pentru literatură.

Rossari, Corinne. 1994. Les opérations de reformulation. Analyse du processus et des marques dans une perspective contrastive français - italien. Berne: Peter Lang.

Vasilescu, Andra. 2009. Elemente de dinamică discursivă a pronumelui. In Gabriela Pană Dindelegan (ed.), Dinamica limbii române actuale - aspecte gramaticale şi discursive. [Dynamics of nowadays Romanian language] 115-162. Bucureşti: Editura Academiei Române.

Zafiu, Rodica. 2012. Conectorii disjunctivi din perspectivă semantico-pragmatică: ipoteze asupra proceselor de gramaticalizare. [The disjunctive connectives from a semantic-pragmatic perspective: hypotheses concerning the grammaticalization processes] Limba Română, LXI (3), 417 - 428.

Received: January 14, 2015

Accepted: January 30, 2016

Published: February 29, 2016

Updated: March 2, 1016 